Children of decolonisation: postcolonial Indo (Eurasian) communities in Indonesia and the Netherlands ${ }^{1}$

In many parts of Asia, the long history of Western colonialism created communities tracing their ancestry to both Asia and Europe, with a cultural heritage that drew from multiple traditions. This article looks at what happened to one such community, Indo-Europeans (or Indos), after Indonesia's independence in 1949. The majority went to the Netherlands, while a smaller number stayed in Indonesia. The long process of decolonisation in both countries has led to diverging memories and identities, with each group drawing on the broader tropes of their national and regional contexts in the ways in which they relate to their past and to each other. Decolonisation, for postcolonial communities that trace their origins beyond national boundaries, did not end with independence and the withdrawal of colonial powers. It is an ongoing process.

Keywords: Indo-Europeans, Indos, Eurasians, decolonisation, Indonesia, memory

\title{
Rosalind Hewett
}

The Australian National University

Rosalind Hewett is a PhD candidate in Pacific and Asian History at the Australian National University.

In many parts of Asia, the long history of Western colonialism created communities tracing their ancestry to both Asia and Europe, with a cultural heritage that drew from multiple traditions. The status of these communities varied greatly under colonialism. British, Dutch, French, Spanish,

\footnotetext{
${ }^{1}$ I would like to express my sincere thanks to Robert Cribb for his many suggestions in the process of writing this article, and Fridus Steijlen, Ronja Eberle and Dario Di Rosa for their comments on earlier drafts. Thanks also to Christine Winter, whose discussions of German-Pacific Islander identity helped me to focus my own ideas. This work was supported by the Australia-Netherlands Research Collaboration under an Australia-Netherlands Research Collaboration PhD Overseas Travel Fellowship, and with the institutional support of the Koninklijk Instituut voor Taal-, Land- en Volkenkunde in October--November 2012.
} 
Portuguese and American authorities responded differently to the outcome of what was sometimes referred to as racial mixing, sometimes seen merely as a form of acculturation. These groups went by many names - Indo-Europeans (Indos) in the Netherlands Indies, Eurasians in Hong Kong, Anglo-Indians in British India, mestizos in The Philippines and métis in French Indochina (e.g. Lee, 2004; Caplan, 2001). In some instances they were despised and distrusted for compromising the social barrier between rulers and ruled, but many occupied a position of intermediary between the metropolitan authorities and local indigenous populations. They did not fully share the privileges of the colonial elite, but they were set in some respects above what were classed as 'natives'.

With the end of empire in parts of Asia after the Second World War, the fate of groups that traced their origins to colonial encounters seemed uncertain. As visible reminders in postcolonial nations of their colonial history, many members of these communities experienced first-hand the upheavals of decolonisation in the often chaotic transition from colony to independent nation. Successive waves of immigrants left for former metropoles to carve out new identities for themselves in nations that were often anxious to forget their colonial past. The demands of decolonisation required these groups to re-think the ways in which they articulated their identities. Scholarly work discussing those who left their homelands tends to frame them as remnants of colonialism, out of place in nations eager to emphasise mono-cultural national identities that did not include the populations of far-flung colonies. Only a few scholars have looked at the members of these groups who were 'left behind' in former colonies (e.g. Winter, 2012; Caplan, 1995; Caplan, 2001).

This article examines how Indo-Europeans (or Indos) in two postcolonial settings draw on a past recounted from the perspective of the present in their contemporary identity constructions. It 
compares the trajectories of Indos in postcolonial Indonesia to Indos in postcolonial Netherlands, where the vast majority settled, through an analysis of life history interviews that I carried out in the Netherlands in 2012 and Indonesia (Java and North Sulawesi) in 2013. Each group drew on the frameworks of their national contexts in defining themselves and other Indos, as well as the broader civilisational constructs of 'East' and 'West. They framed their memories as components of Indonesian or Dutch history, with the omissions, emphases and silences of each. Although each community shared common origins, their diverging experiences on account of decolonisation led to very different postcolonial trajectories.

\section{Indos in the Twentieth Century}

As outlined by Jean Gelman Taylor, a significant proportion of the Netherlands Indies elite prior to the twentieth century were Eurasian (Taylor, 2009). By the twentieth century, the Netherlands Indies government had moved from dividing the population of the colony into categories based on religion to loosely racial categories, consisting of 'Europeans', 'foreign Orientals' and 'natives' (Fasseur, 1994). Each of these categories could include people of mixed descent. An individual's legal status was determined by his or her father's status. If a European father did not acknowledge illegitimate children, legally they were classed as 'native'. Within the European component of society, Indo-Europeans formed a distinct community marked by language, cultural practices and physical appearance. Some classified as European denied their indigenous roots, partly to avoid certain racially-based stereotypes originating in the nineteenth century and perhaps even earlier, such as that Indos were indolent, morally loose and unable to speak proper Dutch (Houben, 2009 71--72; Stoler, 1992). An unknown, much larger number of people legally classed as 'native' had European ancestry, but whether this group of people was also termed 
'Indo' in the Netherlands Indies or not is unclear. A few non-European groups took on European names and adapted certain customs that they traced to their European history, such as the Belanda Depok of Depok, the Mardijkers of Tugu and the orang Borgo of the Minahasa region. However, the former consisted of freed slaves with Dutch surnames, and the latter two traced their ideological, if not ancestral, origins to Portuguese and/or Spanish traders who visited the Indonesian archipelago long before the establishment of a Dutch colony (Cedercreutz, 2003 175).

Indo-Europeans, thanks to their knowledge of Dutch, occupied the lower and middle ranks of the colonial civil service and the Royal Netherlands Indies Army (Koninklijk Nederlands Indisch Leger, KNIL). A small number were involved in travelling Malay language theatre, the Komedie Stamboel (Cohen, 2014), and also, at least at the beginning of the twentieth century, were prolific editors of the Malay language press (Suryadinata, 1971 9). Wider concern among the European community that children of European descent were at risk of 'disappearing into the kampung', or assimilating into the indigenous, poorer areas of colonial cities if they were not sufficiently exposed to 'European' ways of behaving and thinking, led to public concern about the living conditions of this group (Bosma and Raben, 2008 220--223). This concern was one motivation behind the efforts of the Indo Europeesch Verbond, the largest political organisation dedicated to Indo interests in the twentieth century and the much more mainstream successor to Ernest Douwes Dekker's short-lived, nationalist Indische Partij, to raise the living standards of Indos, who increasingly became displaced by educated 'natives', 'foreign Orientals' and an influx of temporary Dutch migrants in their traditional sources of employment, like the civil service, as the century wore on.

During the years of the Japanese Occupation (1942-1945), most Europeans were interned if they could not prove that they had Indonesian ancestry. The majority of Indos stayed outside 
camps (de Jong, 2002; Heidebrink, 2010; Touwen-Bouwsma, 1996). Families cooked, sewed and ran errands to earn enough money to survive after the incomes of civil servants were frozen. With Japanese surrender in 1945, many thought that the 'good old days' of the Netherlands Indies would return, despite Sukarno's declaration of independence on the $17^{\text {th }}$ of August. Between 1945 and 1946, with some justification to extend this period to 1947, groups of young Indonesian men, termed pemuda, targeted and killed Indos and other groups seen as loyal to the colonial administration on the streets of Java and Sumatra (Cribb, 2008; Frederick, 2012). For their own safety, thousands of Indos and Dutch were interned in camps. This period is termed the Bersiap in Dutch historiography.

The Netherlands formally handed over sovereignty to Indonesia after the Dutch-Indonesian Roundtable Conference, held in The Hague from 23 August-2 November 1949. Representatives from Indonesia and the Netherlands agreed to give Indos of European status two years in which to opt for Indonesian citizenship. To begin with, at least, the Indonesian government reassured Indos that they would be safe in the new republic if they chose Indonesian citizenship. Many were hesitant and delayed the decision, perhaps remembering the violence of the Bersiap, but also disinclined to give up the European status that they had strived so hard to maintain in the Netherlands Indies. By the end of 1951, only about 31,000 had chosen to take Indonesian citizenship of an estimated population of about 200,000 Indos of European status (Lucassen and Penninx, 1997 38; Van der Veur, 1960 58--59). Indonesia's own complex political position as a member of the Netherlands-Indonesian Union until 1956 perhaps led to a further impasse and confusion about whether to depart for the Netherlands or not.

All remaining Indos of Dutch citizenship were forced to leave after the Sukarno government expelled Dutch citizens in 1957 over the Dutch New Guinea issue. In 1958 the Indonesian 
government nationalised foreign companies, which had been an important source of employment for many Dutch-educated Indos. By 1960 it had also prohibited school teaching in languages other than Indonesian to Indonesian citizens. About 25,000 of those Indos who had opted to take Indonesian citizenship changed their minds on account of these laws, the increased cost of living as the Indonesian economy struggled through the 1950s, and the political volatility of the Sukarno government's later years. Many who left also cited a Dutch education for their children as one reason for changing their minds, which had assured them a good standard of living in colonial Indonesia. These Indos who changed their minds, termed spijtoptanten in Dutch, were granted loans from the Dutch government to repatriate, with the last few arriving in 1967. The small number of Indos in Indonesia who had formerly held European status disappeared from formal records, along with many others who were legally classified as 'native' in the Netherlands Indies, but also identify as Indo in postcolonial Indonesia.

\section{Indos in the Netherlands}

In the Netherlands, Indos, where they are also known as the Indisch Dutch, comprised a visible group that was often represented in public discourse as an example of a 'successful' minority in comparison to later groups of migrants. ${ }^{2}$ After the Second World War increasing waves of Indos chose to leave Indonesia for the Netherlands. However, it was not until 1957, with the expulsion of Dutch citizens from Indonesia, that they began to attract attention in the media, which depicted them 'as the innocent victims of the difficult process of decolonisation in Indonesia' (Goss, 2000 19). Many were placed in pensions (boarding-houses) with other Indo families, and forced to adapt to a country that most had never set foot in before. A number had to accept lower positions

\footnotetext{
${ }^{2}$ The term 'Indisch Dutch' broadly refers to Dutch born in the Netherlands Indies, including Indos. 'Indisch' itself approximately means Indies. For a discussion of the term 'Indisch' and its meanings, see Cribb (2003).
} 
than those they had filled in the Netherlands Indies, and adjust to life without Indonesian servants. Stories prevailed of wider Dutch ignorance about Indos, who often were termed Indonesiers (Indonesians) in the years following decolonisation.

A small number of these 'repatriates', as they were termed in official Dutch government discourse, later moved to third countries such as the United States. ${ }^{3}$ These transnational communities maintained contact with each other through magazines such as Tong Tong (later Moesson) and De Indo, thanks to the efforts of activists like Tjalie Robinson. Today the members of this generation and their descendants continue to use magazines and online forums to remember the 'good old days' of the Netherlands Indies, the trauma of the Japanese Occupation and the events that followed in independent Indonesia. Broadly, these Indo communities, connected through kumpulan (social gatherings), events such as the annual Tong Tong Fair, the internet and magazines, identify as Dutch speaking, Indies born (or descended from Indies born) people of European and Indonesian descent. Many are active in campaigning for the unpaid backpay of civil servants from the Japanese Occupation, and war reparations for Dutch citizens living in the Indies during the same period.

A number of Dutch Indos are involved in contributing to what they see as a forgotten piece of Dutch history overseas. The written and online histories produced by this group tend to focus on Tempo Doeloe ('the good old days') of the Netherlands Indies (Indië), but also emphasise the events of the Bersiap period and the difficulties that many remember from postcolonial Indonesia, such as discrimination and unemployment, with Indië and Indonesia often represented in a kind of dichotomy. Common terms present in these popular histories and in interviews with members of this generation include Tempo Doeloe, 'trauma' and 'discriminatie' (discrimination).

\footnotetext{
${ }^{3}$ A small number migrated directly from Indonesia to Australia. See Coté and Westerbeek (2005) for a discussion of the Indisch Dutch in Australia.
} 
A number of academic works also chronicle the history of Dutch Indos (Bosma and Raben, 2003; Bosma, Raben and Willems, 2006; Meijer, 2004; Willems, 2001). These books were government funded, part of an official response on the part of the Dutch government to atone for its silence on the role of Dutch Indos in the Netherlands' colonial history, but also to provide a 'gesture', though not necessarily compensation, in recognition of their experiences during the War years (Oostindie, 2010 26; Steijlen, 2009).

In the Netherlands, some of the descendants of those born in the Netherlands Indies also identify as Indo. Young Moesson columnist and YouTube sensation Ricky Risolles, for example, sells tshirts for members of the Dutch Indo community declaring the wearer to be '100\% Puur Indisch' (' $100 \%$ Pure Indisch'). Several of the contemporary identity constructions of this group, including the younger generation, explicitly draw on aspects of a stereotypical 'Asian' identity. Common statements about a Dutch Indo identity include respect for the elderly, the importance of food, and close family bonds, as mentioned by Henny and David Edelman:

An important element of Indo culture, which is due to the heavy influence of Asian culture, is the very clear priority that the family has in life. In Eastern cultures, it is critical to society's judgement of a family's success in life to be able to show that the family bond is strong and that the children behave properly and have good manners (Edelman and Edelman, 2002, 185).

Other statements about Dutch Indos make a distinction between Indos and a broader Dutch identity. One anecdote laughingly repeated by a Dutch Indo family I interviewed in Alkmaar emphasised the generosity of Indo households compared to Dutch households by using the example of a biscuit tin. In Dutch households, they explained, it would be snapped shut after one 
biscuit, but in Indo households, the tin would be left open until all the biscuits were eaten. Broader discussions of food perhaps also employ a similar distinction: the bland potatoes of the Dutch are contrasted with the heavily spiced, rice-based dishes of Indos, possibly implying that Indos are interesting and exotic compared with the 'stolid' Dutch. ${ }^{4}$ Caplan (1995 753) makes a similar point regarding the eating habits of Anglo-Indians in India, in which 'an idealised image of difference is constructed between themselves and other Indians'. In both instances, a (minority) identity is expressed in terms of difference to a dominant majority, and may be seen as a response to the homogenous racial and ethnic categories that many minorities and migrant communities encountered in postcolonial nations.

Dutch Indos and Indonesian Indos maintain a relationship of sorts through Dutch and American charities such as Hulp aan Landgenoten in Indonesië (Help to Compatriots in Indonesia, HALIN), the United States-based Alan Neys Memorial Fund (ANMF) and Help de Indischen in Indonesia (Help the Indisch People in Indonesia). The tiny amount of research carried out to date on Indonesian Indos draws both on the networks enabled through these charities and broader narratives circulating among Dutch Indos about Indos 'left behind', which are also evident in material produced by these charities (Annink, 1994; Pattynama, 1996; Boon, 2004; Van de Loo, 2008). Much of this material draws on the contemporary identity constructions of Dutch Indos in its descriptions of Indos in Indonesia, such as an emphasis on 'Dutchness' and the difficult circumstances that they escaped. Author Vilan van de Loo, who interviewed HALIN recipients in Java, wrote that for these 'former Dutchmen and women... ties with the Netherlands remained: emotional, moral and practical. A colonial past of four centuries could not be erased in a few years...' (Van de Loo, 2008 63) Similarly, a Dutch television program featuring the work of

\footnotetext{
${ }^{4}$ For a discussion of the role of food in constructions of Dutch Indo identity in the Netherlands, see Protschky (2009).
} 
Help de Indischen in Indonesia in East Java, titled 'The Forgotten Elderly of Surabaya', emphasised both the downtrodden circumstances of Indonesian Indos in Surabaya and their ongoing links to the Netherlands:

Among the predominantly Islamic population, almost 100 elderly, invisible Indisch Dutch live scattered throughout the city. They are called Indos. They live in severe poverty. Some live on the street, most without medicine or food and all without a pension. The Indos are Dutch, but cannot prove it, with all subsequent consequences. They all speak Dutch and love our queen. Some even have a Dutch parent. They all have Dutch names. Thus, they are discriminated against and excluded from society (Max Maakt Mogelijk, 2012).

The program closed with a plea from the presenter to its Dutch viewers: 'The Indos here in Surabaya have not had an easy life... They have always felt Dutch. Let them feel that they still belong to the Netherlands. Help the Indos in Surabaya.'

\section{Indos in Indonesia}

A certain percentage of Indonesian Indos born during the 1930s and 1940s do indeed live in difficult circumstances. One contributing factor to their situation is perhaps the relative scarcity of old age pensions provided for Indonesia's elderly population, save those who worked for the government and large companies, which often are not enough in any case to meet basic living costs. Many, though they identified as Indo, formerly held 'native' status and therefore had limited access to a Dutch education. Some were illegitimate children or had lost their fathers in

the 1940s, and were poorly educated as a result, restricting their employment opportunities. Nonetheless a significant number of Indonesian Indos of this generation also live in 
comfortable circumstances. It should be noted here that those who identified as 'Indo' in Indonesia, unlike Indos in the Netherlands, did not necessarily have any direct link to the Netherlands Indies. Some were the children of Dutch soldiers from Indonesia's Revolutionary Period, while others were the children of Western foreigners, including Australians, for example. Nonetheless many members of the generation born during the 1930s, 1940s and 1950s gathered with Indos who did have a direct link to the Netherlands Indies to remember the days of their youth, with no discernible distinctions made between them as might be the case in the Netherlands. This situation indicates that there was a different understanding of what it meant to be Indo in Indonesia compared to the Netherlands, where an Indo identity is tied very much to birth in and memory of the Netherlands Indies.

Although it is difficult to talk of an 'Indo community' in Indonesia, as those who identified as Indo were scattered across Indonesia's many cities and islands, Indos in Indonesia for the most part had contact with other Indos. Sukarno's anti-Dutch rhetoric, and the New Order government's (1966 - 1998) emphasis on conformity to certain state-inscribed ethnic identities restricted the ways in which this group could express or construct a collective identity. Nonetheless the New Order government did feature a number of notable Indonesians with European descent, such as the former commander of the Indonesian Armed Forces (ABRI), Benny Moerdani, and Joop Ave, former Minister of Tourism, Post and Telecommunications. With the beginning of the much more open Reformasi (1998-present) period, as well as their retirement, many Indos in Indonesia began to gather regularly with Dutch speakers, including Indos, leading to an imagined community of sorts, if not a physical community of people living side-by-side. 
Of the forty-five Indos in Indonesia who had some link to the Netherlands Indies, none who had never lived in the Netherlands mentioned an 'Asia' or 'the East', but they did draw on broader narratives in Indonesia about bule (foreigners, usually white). ${ }^{5}$ As outlined by Judith Schlehe, who looked at concepts of Asia and the West in Indonesia, many Indonesians consider this West to consist of 'economic strength and wealth, good-quality products, advanced technology, discipline, a sense of order and punctuality, [and] individualism (seen as independence)...' (Schlehe, 2013 504). Terms mentioned by a number of Indos when describing themselves or other Indos included disiplin (discipline), mandiri (being independent) and being on-time (in English). These terms appeared to be used in opposition to an imagined Indonesian identity that was flexible towards keeping appointments and being on-time. None referred to the darker side of bule as imagined in Indonesia - that they are bebas (promiscuous), individualistic (meaning disconnected from family and community) and irreligious (Schlehe, 2013, 503--504).

Many Indonesian Indos said that they ate bread and drank milk regularly, practices associated with being Western. Two said that Indos were pandai bergaul (good at socialising), a characteristic that did not seem related in any way to an imagined West or an imagined Indonesian identity. One woman in Surabaya mentioned that many Indos were uneducated. None explicitly mentioned the Bersiap period or the pemuda, who are a part of Indonesia's national independence story, though upon being asked a few admitted that there had been violence after Japanese surrender, and that Indonesians in some places refused to sell them food during this time. Many explained that they wanted to stay with family members and so did not apply to repatriate. Indos in Jakarta, Surabaya, Malang, Bandung and Manado mentioned that they had gathered regularly with Dutch-speakers, including other Indos, to remember 'the good old days'

\footnotetext{
${ }^{5}$ In 2012 I interviewed seven people who identified as Indo or Indisch Dutch in the Netherlands. In 2013 I interviewed forty--five Indos in Indonesia who had a connection to the Netherlands Indies.
} 
of their childhoods (not necessarily the Netherlands Indies), or just to speak or re-learn the Dutch that most rarely used in everyday life. Only a few had links with Indo communities outside Indonesia. Several mentioned that they did not really identify with the activities of Dutch Indos, which they read about in magazines or heard about from Dutch Indo expatriates who retired in Indonesia. Almost all considered themselves to be Indonesians with European ancestry.

The following section outlines the life histories of five Indonesian Indos. I have chosen to focus here on the stories of Indonesian Indos to a greater extent than Dutch Indos, as a significant body of previous scholarship has already looked at the life histories of Dutch Indos in detail (e.g. Pattynama, 2000; Coté and Westerbeek, 2005). Their stories are to a certain extent representative of the stories of many Indonesian Indos.

Yan Ferdinandus was one of a handful of Indonesian Indos in contact with Indos in the Netherlands and elsewhere. I met Yan in August 2013 in Surabaya. It was partly thanks to his efforts, with the encouragement of Dutch Indo friends in the Netherlands, that De Indo Club Surabaya was founded in 2006. De Indo Club had organised reunions attended by Indos from the Netherlands and Australia. It provided a forum in which members - not just Indos - could speak Dutch and recall the days of their youth. Yan was the Club's secretary, and he introduced me to several members to be interviewed. When I interviewed Yan, he was awaiting a TV crew from the Netherlands to film a follow-up episode to 'The Forgotten Elderly of Surabaya'. None of the Indos he introduced me to, however, lived in extreme poverty. When I asked Yan why this was the case, he explained that he had not introduced me to those who were very poor because 'I want you to tell a different story about Indos', stories that had not yet been heard or read. He seemed aware of the image of Indonesian Indos in the Netherlands as poor Dutch men and women who continue to experience discrimination, and deliberately set about to counteract it by using me as a 
(non-Dutch) voice to present alternative narratives. Nonetheless those I asked in Indonesia admitted that poverty was indeed an issue for some members of this elderly generation who traced their ancestry to Europe.

Yan spoke to me in a mixture of Indonesian and English. His father was a Dutch soldier in Indonesia during the Revolution, who had returned to the Netherlands before Yan was born in 1947. His mother, whose surname he used, was Ambonese. The only contact Yan had with his father was a letter in 1966 in which his father asked his mother what she wanted in regard to Yan. Dutch soldiers were prohibited from marrying Indonesian women during the Revolution years, and so were unable to bring them back to the Netherlands. A few were unaware that they had fathered children. ${ }^{6}$ Their Indonesian partners in many cases were ostracised and struggled to make a living as single parents. Some put their children in orphanages. As a result, many of these war children were not well educated and unable to obtain good jobs. In Yan's case, his father already had a family in the Netherlands and appeared to want little to do with his illegitimate son. Yan's mother's sold food to pay for his education, and he was able to get a good job in landscaping, and eventually to pay for the university degrees of his own children.

Indirectly through Yan, I met Rudy Damwijk, who was aware of De Indo Club's activities in nearby Surabaya. Rudy's home was set in the green, fertile hills outside Batu in East Java, surrounded by vegetable kebun (market gardens). He had helped representatives from Help de Indischen in Indonesia to find downtrodden Indos in Batu, but he received financial support from HALIN. Rudy was born in 1940 in Surabaya. His mother was Javanese. His Dutch father had died when Rudy was four years old. Rudy recalled, in a mixture of Indonesian and Dutch, that during the Revolutionary Period 'food was difficult to get. Indonesians themselves found it

\footnotetext{
${ }^{6}$ The documentary Tuan Papa outlines the attempts of a number of these Revolutionary children during the Revolution to trace their fathers in the Netherlands (Goedkoop and Wietsma, 2010).
} 
difficult, let alone the Dutch. Because of that, the Dutch quickly left for the Netherlands.' Of Rudy's five siblings, two left Indonesia, with one going to the Netherlands and the other going to Dutch New Guinea, then the Netherlands and finally settling in Australia. Rudy explained that he stayed in Indonesia because his mother did not want to leave. His son-in-law was Dutch, and Rudy's Javanese wife had spent three months in the Netherlands with their daughter and her family. In spite of his father's death when he was young, Rudy still had a relationship to the Netherlands, through HALIN and through his son-in-law

Rudy started working for the Indonesian public service in 1979. He admitted that at the time 'Indos could rarely enter the public service. There was discrimination.' Before applying, he changed his Dutch surname to his grandfather's Javanese surname in his identity card, and also changed his year of birth to 1946 as he was too old to apply. 'If not, I wouldn't have been able to get in.' At first glance, his experience would appear to confirm stories that discrimination towards Indos continued well beyond the 1950s. However, eventually he was able to enter the local public service, suggesting that in his case the main issue hindering his employment was his Dutch surname, rather than his appearance or ancestry.

Yfke Laquais, whom I interviewed in Jakarta in March 2013, suggested that discrimination towards Indos only occurred in the public service; in the private sector, she said, she had never experienced discrimination, nor heard such stories. Yfke was born in 1951. She was of Dutch, Italian, Chinese and Arabic descent. Her home was in an exclusive complex in Jakarta, featuring a Western style kitchen with a dishwasher and porcelain tiles inlaid with pictures of Dutch windmills. Her husband was from New Zealand. Yfke was quite comfortable switching from Indonesian to English when I interviewed her, and from Indonesian to Dutch to English when I observed her interactions at a family kumpulan the following day. Her family consisted mostly of 
Indos. When she was young they had little to do with non-Indos, a trend which had continued among the older generation until today. Her father chose to take Indonesian citizenship in 1951. The family was split after Dutch citizens were ordered to leave Indonesia, with those who had opted for Indonesian citizenship remaining. Nonetheless, they continued to use Dutch and retain the lifestyle they had maintained before independence, such as regular exclusive kumpulan and little contact with non-Indos.

As a child, Yfke played mostly with other Indo children. The aunt who raised Yfke in the absence of her mother strictly controlled how much interaction the children could have with pribumi (indigenous) Indonesians, and called the pribumi maids 'binatang' and 'beesten' (animals). In Yfke's adult life, she said, she had found her aunt's principle that 'you cannot be nice to them [Indonesians]' was true: 'they can't accept kindness... They cheat you.... If you give them a finger they will take your hand.' After her father remarried, the family moved to North Jakarta. Yfke and her siblings found that for the first time they had to play in the street, as their new house was not big enough for them. This meant coming into contact with the pribumi neighbours:

We had to play in the street. Our neighbours' children, the neighbours, everyone came out. They were all looking at us, at our toys. We thought: 'kampung kids, kampung kids!' Because it was normal to think like that; we'd been raised [to think that way] - we were afraid of outsiders. Although actually they weren't really kampung kids, just our neighbours.

When Yfke changed schools from Santa Ursula, an elite private school for Jakarta's upper-class community that included Indos and the children of Indonesia's elite, to Bulungan, where the children 'often brawled, ... it was very, very difficult for me to adjust.' At Santa Ursula, she admitted, 'we were naughty too, but relatively proper. But I think these [students] misbehaved 
like they were kampungan.... They laughed and shouted.... I was really shocked.' In Catholic and Christian schools, she explained, there was discipline. But at Bulungan, even friends encouraged the fighting: 'they ha[d] this animal instinct: 'fight, fight, fight!'... But I wasn't raised like that. So I was quiet. I thought, if I fight, I'll also be kampungan.' After school, she said, she and her mother would go to the home of the child wanting to fight Yfke and discuss the issue by using 'manners, not by fighting in the street'.

Yfke's family strongly reinforced with words such as 'beast' and 'kampung' that the Indonesian maids, the neighbours and even Yfke's classmates were irrevocably different from themselves. Yfke herself acknowledged that 'they felt themselves superior to pribumi'. Nonetheless her family accepted Yfke's Indonesian first husband, who was American educated and whose father had worked for the United Nations. Her use of terms like kampungan, which means the behaviour and way of thinking stereotypically exhibited by villagers, can be seen as an attempt to distinguish her social status from that of Indonesians of a lower class, stereotypically living in the kampung. Her family passed on a mindset that they inherited as members of the European component of Indies society, which emphasised that 'disappearing into the kampung', or assimilating and becoming a 'native', would lead to social shame. Her own mention of the 'animal instinct' of the Indonesian children recounted above suggests that her aunt's characterisation of the Indonesian servants as 'animals' influenced Yfke's interactions with other Indonesians.

Unlike Yfke, Hendricus Moors, whom I met at a kumpulan for Dutch speakers in the hills on the outskirts of Bandung in October 2013, did not distinguish himself from other Indonesians. He admitted, though, that he did not really 'look' Indonesian, with blue eyes and prominent cheekbones. Hendricus was born in 1941 in Magelang, Central Java. He and his Javanese wife 
chose to retire in Bandung. In spite of his obviously foreign looks, Hendricus had never been charged higher prices because, he explained, the moment he opened his mouth and spoke Indonesian, other Indonesians realised that he was not a foreigner. Hendricus's father was Dutch, and his mother was an Indo of Javanese and Belgian descent. His father Joseph, a member of the KNIL, was captured when the Japanese invaded Java in 1942. It was not until 1952, ten years later, that word reached Hendricus's mother that Joseph had died in 1943 as a prisoner of war in Japan. She eventually remarried in 1956, to an Ambonese man who worked in the air force. She never wanted to go to the Netherlands, Hendricus said, though they had family there and Hendricus's brother also chose to emigrate there in 1965. Hendricus said that the main reason he stayed in Indonesia was that someone needed to stay to be with his mother.

Hendricus followed in his step-father's footsteps and applied to enter the air force. It was not until he applied for a civilian passport in 1988, after years of using a military passport, that he realised that according to his birth certificate, he was a European. He was amazed that he had been able to enter the armed forces using a European birth certificate without question, though he thought that perhaps his stepfather's support for his application had some influence, and 'maybe administration wasn't as strict then'. The issue of his European background was only briefly raised during pre-admission testing for the Air Force Academy in Yogyakarta, when generals present during the final round tried to intimidate him by saying, 'this is definitely a poor Dutchman. No Dutchman unless he was poor would want to join AURI [the Indonesian Air Force].' In 1991 he was promoted to colonel. His background, name and appearance seemed to have little relevance to his eventual promotion in the armed forces.

For most of his life, Hendricus had almost no relationship with the Netherlands. His brother who had left for the Netherlands eventually settled in Australia and never returned to Indonesia. 
Around 2006, Hendricus started attending kumpulan for Dutch speakers in Bandung, and began to re-learn the Dutch phrases his mother had used when he was a child. A number of Dutch Indos who were visiting Bandung or had retired there attended the same kumpulan. Through them he became aware of what had happened to other Indos with similar backgrounds to him, now living in the Netherlands and the United States. He emphasised that these Indos were very different to himself:

Those in Indonesia like me don't have any connection with the Netherlands at all, because I lean more towards the Indonesian side, which I can't give up. My eyes may be blue, but yeah, what can I do? I am Indonesian.... Indos living in Indonesia automatically Indonesianised themselves.

He later emphasised repeatedly that 'I can't speak Dutch, I don't know the Netherlands, so I can't feel that I am Dutch. No, I cannot feel it. I don't feel in myself that I am Dutch.' In fact, he said, perhaps he was 'more Indonesian than the Indonesians'. The loss of his Dutch father when he was only a baby, his background in the armed forces and his physical appearance perhaps led him to emphasise an Indonesian identity to a greater extent than many other Indonesians, whose identity was more likely to be taken for granted based on their appearance. His life history to a certain extent provides what he termed the 'missing link' between colonial and postcolonial Indonesia, between the group who left and Indos remaining, who were forced to assimilate (Hewett, 2014).

Yan, Rudy, Yfke and Hendricus were members of a generation seemingly far removed from younger Indos today, who are mostly associated with stardom and success (Kebon 2011). Rafael Klavert's life story provided a bridge not only between the experiences of these two very 
different generations within Indonesia, but also between Indonesian Indos and Dutch Indos. Rafael was born in 1985. He grew up in Indonesia but left when he was fourteen. He was much more comfortable conversing in English than Indonesian when I interviewed him and his wife in Pacific Place, one of the more prestigious malls in Jakarta, in April 2013. His Dutch-speaking grandparents on his father's side were both Indo. Rafael thought that they were introduced through an arranged marriage, as many Indos at the time were discouraged from marrying nonIndos, he said. His grandfather's older brother repatriated to the Netherlands, but his grandparents chose to stay in Indonesia.

Rafael had lived in the Netherlands while undertaking university study. It was there that he became fully aware of the Dutch Indo community through his relatives. He experienced a sort of 'culture shock' in his limited exposure to Dutch Indos:

I don't really relate to them, aside from similarity in terms of ancestry. They are very much Dutch, but they are Dutch who almost worship the Indo Indonesian culture, and they are proud to call themselves half Indo or a quarter Indo or whatever it is. So in that way I didn't really connect with them.... Over there I considered myself a native Indonesian compared to the rest of them.... I found it weird the concept of [an] Indo party, and I was like so only Indos come here, and yeah, 90\% only Indos come here, and I'm like, why?

Rafael saw the definition of 'Indo' in the Netherlands as completely different from 'Indo' in Indonesia:

If you don't look, if you have some sort of non-Indonesian features, be it maybe skin colour is a bit lighter, maybe the eyes are a bit wider, something like that, usually friends [in Indonesia] would call them Indo.... Indo only refers to half Indonesian, half Caucasian.... I 
think Indos in the Netherlands love to call themselves Indo, to claim themselves Indo, whereas... Indo here is just a way to describe someone, he looks Indo for example, whereas in the Netherlands he would say I'm Indo, or hey you're Indo.... I think the Indos in the Netherlands are as I mentioned a lot more passionate about this, a lot more proud of their ancestry....

Rafael had been approached by talent agents in Indonesia five or six times, both as a child and after he returned to Indonesia in 2011, because he 'looked Indo', with light brown eyes. He laughed off these offers to enter the entertainment industry, but mentioned that this kind of thing was the norm for many other members of his generation in Indonesia who 'looked Indo'. His heritage came directly from Indonesia's colonial past, but the responses to his appearance and his background - his own, those he encountered in Indonesia and those in the Netherlands - were the product of a postcolonial world in which both a Eurasian look and mixed ancestry are just as often viewed as interesting, attractive and exotic as they are divergent.

\section{Postcolonial Memory and Identities}

The legacy of colonial legal categories which divided a group with common origins into 'Europeans', 'foreign Orientals' and 'natives' influenced not only whether Indos were able to choose to leave Indonesia, but also their memories and subsequent formulations of identity. Although a number of scholars, beginning with Ann Stoler (1992), have suggested that biological understandings of race from the nineteenth century determined attitudes towards and the everyday experiences of mixed-race communities in European colonies, it was colonial legal categories, to a much greater extent than racial discursive practices, that determined the circumstances of Indos after independence. The implicit requirements of postcolonial citizenship 
further framed the ways in which these groups in Indonesia and the Netherlands could express a collective identity and recount their histories, which were rooted in contemporary understandings of the past.

In the Netherlands, Dutch Indos became involved in grassroots activism, campaigning over issues such as war reparations and wider recognition of the role of Indos in Dutch colonial history. They tended to frame their life histories as an important and forgotten piece of Dutch colonial history, one which included first-hand experiences of decolonisation as they struggled to adapt to changed postcolonial circumstances in both Indonesia and the Netherlands, and convince the Dutch government and society that they were equal Dutch citizens. They expressed their identities in contrast to an imagined Dutch identity, drawing on an 'Asian' heritage to do so. Boundaries about who could be Indo were firmly drawn, with members of this group either born in Indië or descended from someone born in Indië. This Indië was remembered nostalgically as a kind of paradise, almost bittersweet after its postcolonial loss, in contrast to independent Indonesia, which many remembered for its discrimination, anti-Dutch rhetoric and poverty.

In Indonesia, the boundaries of Indo communities were relatively porous. Kumpulan were open to anyone who could speak Dutch, including non-Indos, who wanted to relive the days of their childhood. Indonesian Indos expressed their identities in contrast to an imagined Indonesian identity, drawing on components of what they thought bule or 'the West' were like. They recounted their histories as components of Indonesian history with all its omissions, inclusions and emphases. There was no beautiful Indië, jewel the Netherlands' overseas empire, in their memories, recalled with a sense of loss. None mentioned the Bersiap or the pemuda, though they said that they knew violence towards Dutch men and women, including Indos, had taken place. Years of pressure to assimilate meant that they saw themselves as Indonesian citizens. 
Interactions between Indonesian Indos and Dutch Indos in some ways were uneasy. In the Netherlands, a number of Dutch Indos thought that Indos in Indonesia, whom they had 'left behind', lived in difficult circumstances because of indifference on the part of the Dutch government in the decades following independence, and continued discriminatory and racist practices on the part of the Indonesian government and Indonesian society. A small number of Dutch Indos had retired in cooler Indonesian cities like Bandung and Malang and met regularly with Indonesian Indos. However several Indonesian Indos mentioned that they did not identify with Dutch Indos in spite of their shared historical origins. One man deliberately attempted to counteract images in the Netherlands that Indos only comprised a poor sub-class in Indonesia by using me as an alternative, non-Dutch voice. Another, a member of a younger generation, experienced disjuncture or 'culture shock' when he attended Dutch Indo events in the Netherlands.

In a number of former colonies in Asia, the effects of decolonisation created 'divided peoples' and 'dilemmas of identity', which led to the emergence of reworked and diverging postcolonial identities (Cribb and Narangoa, 2004). These groups have been described by a number of authors in terms of their colonial origins as in, for example, 'children of colonialism' (Caplan, 2001) or 'orphans of empire' (Cribb and Narangoa, 2004). While these terms reflect the shared historical origins of groups that were artificially divided with the end of empires, both the histories and the expressions of identity found among Indo communities in Indonesia and the Netherlands today draw not only on their colonial origins but also on their experiences during decolonisation, and reflect the implicit demands of postcolonial citizenship to conform to national identities. Decolonisation, for these postcolonial communities that trace their origins beyond national 
boundaries, did not end with independence and the withdrawal of colonial powers. It is an ongoing process.

\section{References}

Annink, C. 1994. Orang Indo en Indonesian-Dutch: Indische Nederlanders in Indonesië en de Verenigde Staten van Amerika. In W. Willems and L. Lucassen (eds), Het onbekende vaderland: de repatriëring van Indische Nederlanders (1946-1964). 's-Gravenhage: Sdu Uitgeverij Koninginnegracht, 1994, pp. 147--171.

Boon, L. 2004. 'We zijn als kameleons': Indo's in Indonesië. De sobat: nieuwsbrief voor vonateurs van de stichting Tong Tong April: 20.

Bosma, U. and Raben, R. 2003. De oude Indische wereld, 1500--1920, Amsterdam, B. Bakker.

Bosma, U., and Raben, R. 2008. Being 'Dutch' in the Indies: a history of creolisation and empire,1500--1920. Athens: Ohio, Ohio University Press.

Bosma, U., Raben, R. and Willems, W. 2006. De geschiedenis van de Indische Nederlanders. Amsterdam: Bert Bakker.

Caplan, L. 1995. Creole world, purist rhetoric: Anglo-Indian cultural debates in colonial and contemporary Madras. The journal of the Royal Anthropological Institute 1(4): 743 — 762.

Caplan, L. 2001. Children of colonialism: Anglo-Indians in a postcolonial world. Oxford and New York: Berg.

Cedercreutz, S. 2003. Borgo fishermen: the house, the fish house and the giop sailing boat in North Sulawesi. In S. Sparkes and S. Howell (eds), The house in Southeast Asia: a changing social, economic and political domain. London and New York: RoutledgeCurzon, pp. 171194. 
Cohen, M. 2014. Concerning a certain Komedi Stambul actress. Indonesia and the Malay World 42(122): 113--119.

Coté, J. and Westerbeek, L. 2005. Recalling the Indies: colonial culture and postcolonial identities. Amsterdam: Aksant.

Cribb, R. 2003. 'Indisch' identity and decolonization. IIAS newsletter 31(July): 52 <http://www.iias.nl/iiasn/31/IIASN31_52.pdf> Accessed 22 August 2014.

Cribb, R. 2008. The brief genocide of the Eurasians in Indonesia, 1945/46. In A.D. Moses (ed.), Empire, colony, genocide, conquest, occupation, and subaltern resistance in world history. New York: Berghahn Books, pp. 424--439.

Cribb, R. and Narangoa, L. 2004. Orphans of empire: divided peoples, dilemmas of identity, and old imperial borders in East and Southeast Asia. Comparative studies in society and history 46(1): 164--187.

Edelman, H.N. and Edelman, D.J. 2002. Leisure among retired immigrants: the Indos of the Hague. CMU. Journal 1(2): 177--204.

Fasseur, C. 1994. Cornerstone and stumbling block: racial classification and the late colonial state in Indonesia. In R. Cribb (ed.), The late colonial state in Indonesia: political and economic foundations of the Netherlands Indies, 1880-1942. Leiden: KITLV Press, pp. 3156.

Frederick, W.H. 2012. The killing of Dutch and Eurasians in Indonesia's National Revolution (1945--1949): a 'brief genocide' reconsidered. Journal of genocide research 14(3--4): 359-380.

Goedkoop, H., and Wietsma, A. 2010. Tuan papa. Hilversum: NPS/VPRO. Goss, A. 2000. From Tong-Tong to Tempo Doeloe: Eurasian memory work and the bracketing of Dutch colonial history, 1957-1961. Indonesia 70(October): 9--36. 
Heidebrink, I. 2010. The Eurasian community during the Japanese Occupation, 1943--1945.In P. Post et al. (eds.), The encyclopedia of Indonesia in the Pacific War. Leiden: Brill, pp. 334342.

Hewett, R. 2014. My eyes may be blue but I am Indonesian. Inside Indonesia 118 (Oct--Dec). <http://www.insideindonesia.org/feature-editions/my-eyes-may-be-blue-but-i-am-indonesian> Accessed 10 November 2014.

Houben, V.J.H. 2009. Boundaries of race: representations of Indisch in colonial Indonesia revisited. In H. Fisher-Tin and S. Gehrmann (eds.), Empires and boundaries: race, class and gender in colonial settings. New York: Routledge, pp. 66--85.

Jong, L. de 2002.The collapse of a colonial society: the Dutch in Indonesia during the Second World War. Leiden: KITLV Press.

Kebon, A. 2011.Stars and stereotypes. Inside Indonesia 103(Jan--March). <http://www.insideindonesia.org/weekly-articles/stars-and-stereotypes> Accessed 14 August 2014.

Lee, V. 2004.Being Eurasian: memories across racial divides. Hong Kong: Hong Kong University Press.

Lucassen, J. and Penninx, R. 1997. Newcomers: immigrants and their descendants in the Netherlands 1550--1995. Amsterdam: Het Spinhuis.

Max Maakt Mogelijk 2012. Vergeten ouderen Surabaya. <http://www.maxmaaktmogelijk.nl/projecten/indonesie/vergeten-ouderen-surabaya/> Accessed 7 August 2014.

Meijer, H. 2004. In Indië geworteld: de twintigst eeeuw. Amsterdam: B. Bakker. Oostindie, G. 2010. Postcolonial Netherlands: sixty--five years of forgetting, commemorating, 
silencing. Translated by A. Howland. Amsterdam: Amsterdam University Press.

Pattynama, P. 1996. Ik woon hier and ik hoor hier. Indo's in Indonesië. Hoe is het hun vergaan? Pasarkrant November: 8.

Pattynama, P. 2000. Assimilation and masquerade: self-constructions of Indo-Dutch women. European journal of Women's Studies 7(3): 281--299.

Protschky, S. 2009. The flavour of history: food, family and subjectivity in two Indo-European women's memoirs. The history of the family 14(4): 369-385.

Schlehe, J. 2013. Concepts of Asia, the West and the Self in contemporary Indonesia. South East Asia 23(3): 497--515.

Steijlen, F. 2009. Remembrance of Dutch war dead in Southeast Asia, 1942--1945. Public history review 16:64--77.

Stoler, A.L. 1992. Sexual affronts and racial frontiers: European identities and the cultural politics of exclusion in colonial Southeast Asia. Comparative studies in society and history 34(3): 514--551.

Suryadinata, L. 1971. The pre-World War II peranakan Chinese press of Java: a preliminary survey. Athens, Ohio: Ohio University Center for International Studies.

Taylor, J.G. 2009. The social world of Batavia: Europeans and Eurasians in colonial Indonesia. $2^{\text {nd }}$ edition. Madison, Wisconsin: The University of Wisconsin Press.

Touwen-Bouwsma, E. 1996. Japanese minority policy: the Eurasians on Java and the dilemma of ethnic loyalty. Bijdragen tot de taal-, land-en volkenkunde 152(4): 553--576.

Van de Loo, V. 2008. Familie gebleven: hulp aan landgenoten in Indonesië. De Rijp: Orange House.

Van der Veur, P.W. 1960. Eurasian dilemma in Indonesia. The journal of Asian Studies 20(1): 
45--60.

Willems, W. 2001.De uittocht uit Indië: 1945--1995. Amsterdam: Bakker.

Winter, C. 2012. Changing frames: identity and citizenship of New Guineans of German heritage during the interwar years. The journal of Pacific history 47(3): 347-367. 